\title{
doispontos:
}

\section{Do grito do incondicionado aos ruídos do tempo: Gilles Deleuze e a questão do princípio do prazer}

\author{
Flávio Luiz de Castro Freitas ${ }^{1}$ \\ f_lcf@hotmail.com \\ Universidade Federal do Maranhão
}

Resumo: Investigação que tem por objetivo explicitar a interpretação filosófica de Gilles Deleuze acerca do texto Além do princípio do prazer, de Sigmund Freud de 1920. Para tanto, postula-se que nos trabalhos Sacher-Masoch, O frio e o cruel de 1967 e Diferença e repetição de 1968, Deleuze se apropria do aspecto "especulativo" de fundo metapsicológico-econômico presente no texto de Freud. Essa apropriação é de ordem crítica, transcendental e genealógica, tanto num âmbito esquemático quanto numa perspectiva conceitual. Como resultante dessa apropriação, surgem importantes críticas ao modelo da repetição material e ao modelo objetivo da morte em Freud, bem como a constatação de que, para Deleuze, o tempo é a condição para que o prazer seja em última instância sustentado como princípio.

Palavras-chave: Deleuze; Freud; psicanálise; transcendental; repetição; tempo.

Abstract: Research that aims to describe the philosophical interpretation of Gilles Deleuze about the text Beyond the pleasure principle of Sigmund Freud de1920. Therefore, it is postulated that in Sacher-Masoch. The cold and cruel - 1967 and Difference and Repetition - 1968 Deleuze appropriates of the aspect "speculative" the metapsychological-economic background present in Freud's text. This appropriation is critical order, transcendental and genealogic, both in schematic level, as a conceptual perspective. As a result of this ownership, there are important criticisms of the material repetition model and the objective model of death in Freud, as well as the realization that, for Deleuze, time is the condition for the pleasure is in the final instance sustained as a principle.

Keywords: Deleuze; Freud; psychoanalysis; transcendental; repetition; time.

\section{INTRODUÇÃO}

O pensamento filosófico de Gilles Deleuze estabelece relações relevantes com a psicanálise em pelo menos dois momentos. O primeiro momento, que pode ser chamado de "crítica conciliável", tem início em 1967 com a publicação de Sacher-Masoch - O frio e o cruel. Em seguida, atravessa Diferença e repetição, de 1968, e encontra seu termo em Lógica do sentido, de 1969. Esse primeiro bloco de pensamento pode ser caracterizado pelo início da construção do projeto chamado de "crítica e clínica". Em linhas gerais, semelhante projeto busca relacionar, dentro da pesquisa filosófica, sintomatologia, tipologia e genealogia. Talvez seja o exercício deleuzeano para contribuir com o programa do "filósofo como artista e médico da civilização", o qual ele apresentou desde Nietzsche e a filosofia em 1962.

É cabível perguntar pelas razões necessárias que impulsionaram o pensamento de Deleuze na direção da crítica conciliável em relação à psicanálise, pois até 1966 ele não havia publicado um livro que abordasse de maneira explícita, direta e prioritária esse saber. Em que pesem as menções a Freud nos textos da década de 50, como, por exemplo, em seu primeiro livro, Empirismo e subjetividade, e no artigo sobre 
Bergson, A concepção da diferença segundo Bergson, a psicanálise começa a ser investigada com rigor crítico por Deleuze a partir de Sacher-Masoch em 1967.

Supomos que existem pelo menos duas razões para essa aproximação entre sua obra voltada até então para a história da filosofia de contornos procedimentais de cunho estruturalista e o saber psicanalítico. A primeira delas é que entre as décadas de 60 e 70 a psicanálise era uma das forças hegemônicas que se ocupava do tema do pensamento. A segunda razão é que o próprio Deleuze, no livro sobre Nietzsche, já havia exercitado a procura por um princípio para o pensamento que fosse capaz de afirmar a alegria do múltiplo.

O segundo momento ou segundo bloco das relações entre o pensamento de Deleuze e a psicanálise pode ser chamado de "ruptura" e começa com a publicação do primeiro volume do projeto "Capitalismo e esquizofrenia", cujo título é $O$ Anti-Édipo, de 1972. O volume seguinte desse projeto é o texto chamado de Mil Platôs de 1980. Entre esses dois volumes foi publicado ainda um livro intitulado de Kafka: por uma literatura menor em 1975.

Esse segundo bloco de pensamento pode ser caracterizado, biograficamente, pelo encontro de Gilles Deleuze com Félix Guattari, o qual precipita a saída do primeiro da crítica conciliável em relação à psicanálise. ${ }^{2}$. Essa fase não é propriamente um tipo de antipsicanálise, todavia é marcada por uma ambiguidade necessária em relação a esse saber, tal qual pode ser constatado no projeto da esquizoanálise apresentado no capítulo 4 de $O$ Anti-Édipo.

Na verdade, nos termos da necessidade inerente ao movimento do ato de pensar, trata-se de uma radicalização dos limites encontrados na pesquisa exposta em Lógica do sentido. Mais especificamente, é o limite entre a perversão e a esquizofrenia enquanto procedimentos e modelos metodológicos, bem como é o canto da pura necessidade da parte de Deleuze ao aproximar o conceito de corpo sem órgãos da ideia de inconsciente maquínico desenvolvida por Guattari.

É curioso, não fui eu quem tirou Félix da psicanálise, mas ele que me tirou dela. Em meu estudo sobre Masoch, e depois na Lógica do sentido, eu acreditava ter obtido resultados sobre a falsa unidade sadomasoquista, ou ainda sobre o acontecimento, que não estavam em conformidade com a psicanálise, mas que podiam conciliar-se com ela. Félix, ao contrário, era e continuava sendo psicanalista, aluno de Lacan, mas à maneira de um "filho" que já sabe que não há conciliação possível (DELEUZE, 1992, p. 180).

Para fins de delimitação heurística, dentro do contexto da crítica conciliável dirigida à psicanálise, o objetivo do presente trabalho consiste em explicitar a interpretação filosófica de Gilles Deleuze acerca do texto Além do princípio do prazer de Sigmund Freud, de 1920. A compreensão de Deleuze a respeito de Além do princípio do prazer está exposta em distintos lugares de sua obra, visto que é um texto citado com certa frequência em seus trabalhos da década de 60. Porém, existem duas ocasiões marcantes nas pesquisas deleuzeanas: Sacher-Masoch. O frio e o cruel de 1967 e Diferença e repetição de 1968. Em ambos os livros, do ponto de vista de sua leitura de Freud, Deleuze investiga o mesmo problema e suas eventuais consequências: em que medida, filosoficamente, o prazer pode ser considerado como um princípio?

Nossa hipótese de leitura postula que a interpretação filosófica de Deleuze se apropria do aspecto "especulativo" de fundo metapsicológico-econômico presente no texto de Freud. Sua apropriação é de ordem crítica, transcendental e genealógica, tanto num âmbito esquemático quanto numa perspectiva conceitual.

Como resultante dessa apropriação, surgem importantes críticas ao modelo da repetição material e ao modelo da morte em Freud. Na primeira ocasião essa apropriação ocorre no contexto da construção do projeto de uma crítica (literária) ligada à clínica (médica). Na segunda ocasião, que por sua vez absorve 
os argumentos da primeira, a apropriação ocorre dentro dos limites do projeto de pensar a diferença em si mesma, estando necessariamente relacionada à "repetição para si”.”

Desse modo, para desenvolver essa hipótese, iremos caracterizar o princípio do prazer em Além do princípio do prazer de Freud. Em seguida, descreveremos como ocorre a interpretação que Deleuze realiza desse texto em Sacher-Masoch - O frio e o cruel. Por fim, faremos a exposição da maneira como Deleuze compreende o problema do prazer enquanto princípio em Diferença e repetição.

\section{UMA LEITURA DE ALÉM DO PRINCÍPIO DO PRAZER ${ }^{4}$ DE FREUD}

De acordo com a hipótese apresentada por Freud no início da linha argumentativa da parte I do referido trabalho de 1920, o princípio do prazer é a tendência que rege o curso dos eventos mentais no sentido de evitar o desprazer e produzir o prazer. A direção desse curso decorre da movimentação desencadeada por uma tensão desagradável, cujo resultado final coincide com a redução dessa mesma tensão. $O$ desprazer e o prazer estão relacionados à quantidade de excitação não vinculada que está presente no aparelho psíquico.

Na teoria da psicanálise não hesitamos em supor que o curso tomado pelos eventos mentais está automaticamente regulado pelo princípio de prazer, ou seja, acreditamos que o curso desses eventos é invariavelmente colocado em movimento por uma tensão desagradável e que toma uma direção tal, que seu resultado final coincide com uma redução dessa tensão, isto é, com uma evitação de desprazer ou uma produção de prazer (FREUD, 1976, p. 17).

No caso do desprazer, ele corresponde a um aumento na quantidade de excitação, e o prazer significa uma diminuição na quantidade de excitação. Freud elucida que isso não conduz, necessariamente, no rumo de uma relação de correspondência proporcional entre as intensidades dos sentimentos de prazer e desprazer e as modificações na quantidade de excitação. Existem elos entre as sensações qualitativas e as quantidades econômicas, mas elas não possuem uma identificação direta e proporcional.

Para Freud, esse tipo de perspectiva acerca da vida psíquica corresponde ao ponto de vista econômico e sua eventual descrição pode ser considerada como sendo metapsicológica. Assim, um dos pontos de partida da linha argumentativa apresentada por Freud consiste em afirmar que a hipótese do princípio do prazer é um produto da tentativa de descrever e explicar os fatos pertinentes à observação no campo psicanalítico.

A linha argumentativa desenvolvida por Freud em Além do princípio do prazer é direcionada no sentido de identificar as circunstâncias e as forças capazes de contradizer o domínio do princípio de prazer. Freud confronta seu trabalho analítico, acompanhado de sua hipótese do princípio do prazer, com duas ocasiões: o princípio de realidade e a repressão pulsional decorrente dos conflitos que ocorrem no aparelho mental durante o desenvolvimento do ego.

O princípio de realidade, na hipótese de Freud, é compreendido como fruto da influência das pulsões de autopreservação do ego sobre o princípio do prazer, visto que este princípio é o método primário de funcionamento do aparelho psíquico e, por consequência, do ponto de vista da autopreservação do organismo, é considerado ineficaz e perigoso. Entretanto, o princípio de realidade não abandona o propósito de obter prazer, mas ele exige e efetua o adiamento da satisfação, culminado numa tolerância temporária ao desprazer como uma etapa longa e indireta até o mesmo. O princípio de prazer persiste como método 
de funcionamento usado pelas pulsões sexuais e, frequentemente, com base nessas pulsões ou no próprio ego, ele consegue vencer o princípio de realidade.

No que tange à repressão pulsional, Freud expõe que em quase sua totalidade a energia responsável por abastecer o aparelho psíquico é resultante de impulsos pulsionais inatos. Contudo, nem todos esses impulsos atingem os mesmos estágios de desenvolvimento, pois pode existir uma incompatibilidade, no que concerne aos objetivos e exigências, entre pulsões sexuais individuais, partes de algumas dessas pulsões e as pulsões remanescentes que podem vir a ser combinadas na unidade do ego. Como efeito dessa incompatibilidade, as pulsões individuais são expelidas dessa unidade mediante a repressão, bem como são mantidas em níveis inferiores de desenvolvimento psíquico e afastadas da possiblidade de satisfação. Caso essas pulsões conduzam, por caminhos indiretos, à satisfação, esse feito é sentido pelo ego como desprazer.

Acerca disso, Freud argumenta que a maior parte do desprazer que experimentamos é de ordem perceptiva, pois ainda que esse desprazer possa ser a percepção de uma pressão por parte de pulsões insatisfeitas ou a percepção externa de algo que causa aflição, o princípio de prazer ou princípio de realidade, que é o primeiro modificado, estarão trabalhando de maneira eficaz. Isso ocorre devido a semelhante percepção ser uma reação do aparelho psíquico, cujo fundo é conduzido pelos princípios mencionados.

Em seguida, a argumentação de Freud se move na direção dos sonhos que ocorrem nas neuroses traumáticas, da brincadeira das crianças, da representação e da imitação artísticas encenadas por adultos, isto é, a parte II de Além do princípio do prazer. Supomos que Freud utilize esses três tipos de situações para mostrar, a princípio, que eles não contradizem a dominância do princípio do prazer e, por consequência, aquilo que é exposto como fruto do trabalho do campo psicanalítico. No entanto, nesse ponto, é apropriado frisar duas inserções no argumento de Freud em relação ao que foi apresentado até então no texto de 1920: a recorrência ao tema da repetição e a menção ao funcionamento de tendências que podem estar "Além" do princípio do prazer.

Eles não têm utilidade para nossos fins, pois pressupõem a existência e a dominância do princípio de prazer; não fornecem provas do funcionamento de tendências além do princípio de prazer, ou seja, de tendências mais primitivas do que ele e dele independentes (FREUD, 1976, p. 29).

É oportuno lembrar, que embora a estratégia argumentativa utilizada por Freud ao longo das partes I, II e III de Além do princípio do prazer seja aparentemente estéril, ela pode ser entendida também como um procedimento de "arranque" que culmina na afirmação, ao final da parte III, da existência de uma "compulsão à repetição" independente em relação ao princípio do prazer (MONZANI, 2014, p. 151).

Portanto, em se tratando da repetição, ela é descrita por Freud a partir tanto dos sonhos que ocorrem nas neuroses traumáticas quanto da brincadeira das crianças. As repetições que acontecem nos sonhos das pessoas acometidas de neuroses traumáticas têm como característica marcante levar o paciente de volta à situação de seu acidente. Contudo, Freud adverte que, caso essa repetição seja entendida como evidente por si mesma, pode comprometer a compreensão acerca da natureza dos sonhos, a qual consiste no caráter realizador de desejos reprimidos. Assim, Freud apresenta duas possiblidades para os sonhos que acontecem nas neuroses traumáticas. A primeira possibilidade postula que a função de sonhar, nessa condição, está perturbada e distante de seus propósitos. A segunda possiblidade encaminha a especulação metapsicológica para considerar esses sonhos com base nas tendências masoquistas do ego.

Já a brincadeira das crianças é compreendida como o método de funcionamento empregado pelo aparelho mental em suas primeiras atividades normais. Mais especificamente no caso do jogo do desaparecimento e retorno, Freud interpreta que seja a grande realização cultural da criança, isto é, a renúncia pul- 
sional ou a renúncia à satisfação pulsional. Essa renúncia é o processo de transição, mediante repetição, de uma situação passiva dominada pela experiência e pela aflição para uma circunstância ativa marcada pela característica do jogo.

No caso das representações e encenações artísticas, Freud entende que elas não poupam os expectadores das mais penosas experiências, mas são sentidas por eles como altamente prazerosas. Isso nos remete para a segunda inserção na linha argumentativa de Freud, pois para ele o traço em comum desses três tipos de situações é que não fornecem provas do funcionamento de tendências que estão "Além" do princípio do prazer. O "Além" significa a possível existência de tendências mais primitivas e independentes em relação ao princípio do prazer, isto é, a busca está direcionada para algo supostamente mais elementar que não dependa do princípio do prazer.

A etapa posterior da argumentação de Freud, parte III, pode ser considerada, em certo sentido, uma continuidade do tema da repetição, pois Além do princípio do prazer menciona explicitamente, nesse ponto, a noção de "compulsão à repetição" e, em seguida, problematiza a função da mesma, bem como as condições de seu surgimento e a natureza de sua relação com o princípio do prazer.

A compulsão à repetição deve ser atribuída ao reprimido inconsciente enquanto manifestação do poder deste. Ela também está relacionada aos sonhos que ocorrem nas neuroses traumáticas e ao impulso que conduz as crianças a brincarem. Para que a compulsão à repetição possa se expressar, requer que o trabalho analítico tenha avançado consideravelmente e afrouxado a repressão dos pacientes. A resistência do ego consciente e inconsciente funciona de acordo com a influência do princípio do prazer, vindo a evitar o desprazer que é produzido pela liberação do reprimido.

Segundo Freud, os esforços do tratamento psicanalítico estão voltados para conseguir determinada tolerância a esse desprazer por meio do princípio de realidade. Aquilo que é reexperimentado na compulsão à repetição causa desprazer no ego, pois traz à tona as atividades dos impulsos pulsionais reprimidos. Esse desprazer não contradiz o princípio de prazer, porque pode ser desprazer para um sistema, porém funciona como prazer para outro. Nessa parte, o argumento de Freud esclarece que a compulsão à repetição também rememora do passado experiências que não incluem possiblidade alguma de prazer e que nunca trouxeram satisfação: são atividades de pulsões que são repetidas sob a pressão de uma compulsão que conduziu em algum momento ao desprazer.

Com base nisso, a partir dos fenômenos de transferência dos neuróticos, e até mesmo nos relatos corriqueiros de homens e mulheres, Freud supõe que existe no aparelho mental uma compulsão à repetição que sobrepuja o princípio de prazer. Hipoteticamente, ao final da parte III de Além do princípio de prazer, Freud entende que a compulsão à repetição é algo mais primitivo, mais elementar e pulsional do que o princípio de prazer: "Resta inexplicado o bastante para justificar a hipótese de uma compulsão à repetição, algo que parece mais primitivo, mais elementar... do que o princípio de prazer que ela domina" (FREUD, 1976, p, 37).

Isso remete à linha argumentativa para o passo seguinte, o qual corresponde especificamente à parte IV. Freud afirma que irá realizar uma "especulação forçada". Essa especulação é também chamada de "psicanalítica" e deriva do exame dos processos inconscientes. Semelhante "especulação psicanalítica" está baseada nas observações de fatos pertinentes ao "campo de estudo" do "trabalho psicanalítico".

O caminho adotado pela sua argumentação consiste em retomar os sonhos que acontecem nas neuroses traumáticas, visto que eles são considerados exceções à ideia de que os sonhos são realizações de desejos. Os sonhos que ocorrem nas neuroses traumáticas surgem devido à compulsão à repetição (FREUD, 1976, p. 48). Sua função pode ser considerada anterior à realização dos desejos reprimidos. 
Para desenvolver esse aspecto de sua ideia, Freud parte da impressão de que a consciência pode ser uma função especial dos processos mentais. De um ponto de vista metapsicológico, Freud assevera que a consciência é uma função do sistema $C$ s. O produto da consciência é essencialmente composto por percepções de excitações oriundas do mundo externo e de sentimentos de prazer e desprazer que surgem, exclusivamente, do interior do aparelho psíquico. Como efeito disso, Freud entende que o sistema Pcpt-Cs possui uma posição no espaço, a qual é o limiar entre o interior e o exterior.

O modelo utilizado por Freud para sustentar essas especulações pertence à anatomia cerebral, que por sua vez identifica a sede da consciência no córtex cerebral, o qual está situado na parte mais extrema do cérebro. Freud salienta que a anatomia cerebral não tem necessidade de questionar as razões que levam a consciência a ficar situada na superfície do cérebro, permitindo que a especulação psicanalítica aborde esse problema por meio do sistema $P$ cpt-Cs. É prudente lembrar que a função da aproximação junto ao modelo biológico consiste em permitir que Freud retome, em linhas gerais, a estrutura e a gênese do aparelho psíquico.

O pressuposto que funciona como ponto de partida para Freud investigar essa questão é composto pelas impressões derivadas da experiência psicanalítica, segundo o qual todos os processos excitatórios que acontecem nos demais sistemas relegam atrás de si traços permanentes que funcionam como fundamento da memória. O elemento específico do sistema $C s$ é que os processos excitatórios se tornam conscientes sem deixar traço permanente algum atrás de si. Todavia, a excitação é transmitida aos sistemas seguintes juntamente com seus respectivos traços.

Precisamente nessa parte, a linha argumentativa de Freud realiza outro movimento e, embora continue a fazer uso do modelo biológico, se aproxima da embriologia e de sua relação com a filogênese, como referência para sua especulação: "Na verdade, a embriologia, em sua capacidade de recapituladora da história desenvolvimental, mostra-nos realmente que o sistema nervoso central se origina do ectoderma" (FREUD, 1976, p. 41).

Nesse sentido, o modelo embriológico-filogenético é utilizado, especulativamente, para pensar sobre a origem da consciência em alusão aos sistemas componentes do aparelho psíquico. Trata-se do desenvolvimento imaginativo de uma vesícula viva e suas respectivas transformações devido ao contato e receptividade com estímulos externos. Especificamente, o impacto incessante de estímulos externos sobre a superfície dessa vesícula produziria um curso distinto daquele que é vivenciado nas camadas mais profundas.

Nesse caso, é formada uma crosta calcinada pela estimulação, cujo efeito é ter se tornado mais favorável para recepção de estímulos e incapaz de uma nova modificação. Essa hipótese significa, nos termos do sistema $C$ s, que seus elementos não podem experimentar novas modificações permanentes pela passagem de excitação, como decorrência da modificação anterior, pois logo estariam colocadas as condições para o surgimento da consciência dentro dos limites das peculiaridades dos processos excitatórios que ocorrem no sistema $C s$.

Esse modelo biológico permite que Freud aborde os sonhos que ocorrem nas neuroses traumáticas, destacando que a função desses sonhos consiste em retornar regularmente à situação na qual o trauma aconteceu. Esse retorno tem o objetivo ou tarefa de "dominar retrospectivamente o estímulo, desenvolvendo a ansiedade cuja omissão constituiu a causa da neurose traumática” (FREUD, 1976, p. 48). Essa função de dominar o estímulo não contradiz o princípio do prazer, no entanto atua de maneira mais primitiva e independente em relação a ele.

Em relação a isso, o conceito de trauma adquire destacada importância. $\mathrm{O}$ trauma significa ruptura numa barreira que seja eficaz contra os estímulos. No trauma ocorre um distúrbio no funcionamento do 
organismo. Em paralelo, o princípio de prazer é colocado fora de ação, cujo efeito extremo gera o problema do domínio de grandes quantidades de estímulos e de vincular psiquicamente os mesmos para que tais estímulos possam ser desvencilhados.

Durante essa invasão ao aparelho psíquico, a energia catéxica é convocada de distintos lugares para fornecer catexias elevadas ao redor da ruptura onde aconteceu a invasão. Em seguida, uma anticatexia é estabelecida em detrimento de todos os outros sistemas psíquicos, fazendo com que todas as funções psíquicas sejam paralisadas ou reduzidas. Então, Freud supõe que o processo excitatório pode ser executado com energias capazes de variar quantitativamente.

Combinado a isso, o processo excitatório pode ter mais de uma qualidade, permitindo que seja feita a diferenciação entre dois tipos de catexias: catexia livre que flui livremente no sentido da descarga; e catexia vinculada. Como decorrência dessa suposição, Freud suspeita que "a vinculação da energia que flui para dentro do aparelho mental consiste em sua mudança de um estado de fluxo livre para um estado quiescente" (FREUD, 1976, p. 47).

Com isso, essa diferença qualitativa do ponto de vista energético também permite localizar com maior precisão o núcleo da atividade que corresponde ao "Além" em relação ao princípio do prazer. Essa atividade é a ligação da energia livre para torná-la quiescente. Isso reafirma os vínculos entre dois conjuntos de noções, cuja mediação é operada pela atividade de ligação. No primeiro conjunto estão as noções de livre fluxo, energia livre e processo primário. No segundo conjunto estão as noções de vinculação, energia ligada e processo secundário.

Esse argumento adquire contornos mais explícitos e diretos com sua formulação ao final da parte III por meio da hipótese da independência da compulsão à repetição em relação ao princípio do prazer. Todavia, a consistência específica e precisa dessa parte do argumento é apresentada na ideia de que a ligação é responsável por essa tarefa de cunho mais independente e mais elementar do que o princípio do prazer.

Desse modo, seguindo sua linha argumentativa, Freud adentra na parte V e utiliza como referência os distúrbios econômicos das neuroses traumáticas para considerar os efeitos das transmissões de estímulos internos sobre a camada cortical isenta de escudo protetor. Esses efeitos são comparáveis aos das neuroses traumáticas. As respectivas fontes de excitação interna são as pulsões do organismo que se originam no interior do corpo e são transmitidas ao aparelho mental. Esse aspecto de seu argumento Freud desenvolve desde o final da parte IV e consiste na construção de uma série de analogias: dor física, dor psíquica e intensidade pulsional.

As pulsões são processos livremente móveis e correspondem ao processo primário, em oposição aos processos vinculados que correspondem ao processo secundário. Cabe à ligação sujeitar a excitação pulsional que atinge ao processo primário, pois, do contrário, poderia haver um distúrbio semelhante ao da neurose traumática, cuja implicação seria uma impossibilidade da dominância do princípio do prazer: "Até então, a outra tarefa do aparelho mental, a tarefa de dominar ou sujeitar as excitações, teria precedência, não na verdade, em oposição ao princípio de prazer, mas independentemente dele e, até certo ponto, desprezando-o" (FREUD, 1976, p. 52).

No passo seguinte, o argumento de Freud avança numa direção um pouco diferente, pois recorre, de novo, às manifestações da compulsão à repetição: as primeiras atividades da vida mental infantil e os eventos do tratamento psicanalítico. No primeiro caso não há contradição ao princípio do prazer, pois a repetição é uma fonte de prazer em si mesma. Porém, o segundo caso, que é composto pela compulsão à repetição dos eventos da infância, parece contrariar a ligação que expusemos antes, uma vez que despreza o princípio do prazer em todos os seus aspectos. "No caso de uma pessoa em análise, pelo contrário, a 
compulsão à repetição na transferência dos acontecimentos da infância evidentemente despreza o princípio de prazer sob todos os modos" (FREUD, 1976, p. 53).

Isso ocorre devido aos traços de memória reprimida não estarem em estado de sujeição e com dificuldade de obedecer ao processo secundário, isto é, parecem existir sinais de que não houve a ligação ou ocorreu uma "falha" (MONZANI, 2014, p. 174) na ligação. É nesse caso, precisamente, que a compulsão à repetição pode ser considerada como oposição ao princípio do prazer.

No momento seguinte de sua argumentação, Freud começa a abordar o tema das pulsões de morte mediante a seguinte questão: qual é a natureza da relação entre pulsão e compulsão à repetição? Semelhante problema pode ser considerado o ponto de introdução do tema das pulsões de morte em Além do princípio do prazer, uma vez que até então essa ideia não havia sido apresentada explicitamente no texto de Freud.

Esse problema é colocado entre o tema da possiblidade da falha na ligação e o tema das pulsões de morte. Mais especificamente, trata da emergência de uma compulsão à repetição que funciona em oposição ao princípio do prazer e atua de forma "demoníaca”, para fazer uso da expressão do próprio Freud.

Freud explicita que, em Além do princípio do prazer, a pulsão é um impulso inerente à vida orgânica, o qual está voltado para restabelecer determinado estado anterior das coisas. Sua relação com a compulsão à repetição está alicerçada sobre a ideia de que existe um impulso direcionado a repetir. Do ponto de vista de um modelo que permite a aproximação com um suposto campo de testes para apoiar sua especulação rica em contornos metafóricos, Freud recorre mais uma vez à biologia, citando os fenômenos da hereditariedade e os fatos da embriologia, dentre os quais destaca a evolução de um germe qualquer de animal vivo, que é capaz de recapitular as estruturas de todas as formas das quais se originou.

Recorrer à biologia não significa raciocinar de maneira direta sobre o progresso dos seres vivos, mas consiste em considerar o processo de "intricamento", ${ }^{5}$ dotado de destruição e construção, como modelo epistêmico capaz de fornecer condições para pensar, de maneira próxima, a sexualidade humana e a evolução dos seres vivos. Por isso, nesse modelo há uma estrutura dualista em funcionamento.

Retomando a evolução do germe de animal vivo, Freud também frisa o poder de regeneração de um órgão perdido, fazendo com que o outro venha a nascer semelhante ao anterior. Esses casos de compulsão à repetição não são compreendidos por Freud como situações meramente mecânicas, porém são portadores de algo anteriormente existente que torna a se manifestar. Portanto, no entendimento de Freud, as pulsões direcionadas para o retorno ao inorgânico são correspondentes à compulsão à repetição.

Como consequência disso, Freud supõe que todas as pulsões orgânicas são conservadoras, adquiridas historicamente e tendem para a restauração de um estado anterior das coisas. Seguindo seu corolário, Freud afirma que os fenômenos do desenvolvimento orgânico são decorrentes de influências externas que são desviadoras e perturbadoras, pois desde seu início a vida elementar não almeja mudar, contudo, toda modificação que ela sofre como efeito do desenvolvimento dos organismos viventes é aceita pelas pulsões conservadoras e armazenada para sua posterior repetição.

Essa repetição está ligada ao objetivo final das pulsões conservadoras, as quais fornecem uma aparência enganosa de serem tendências no sentido da mudança e do progresso. Em meio a essa aparência, as pulsões conservadoras buscam alcançar seu objetivo tanto por caminhos novos quanto por caminhos já conhecidos. Esse objetivo é caracterizado por Freud como sendo um estado de coisas antigo, um estado inicial do qual a entidade viva, de algum modo, se afastou e tenta retornar por meio de longas mediações ocorridas no decorrer de seu desenvolvimento. O objetivo último das pulsões conservadoras consiste 
em morrer e voltar cada vez mais para trás, no momento em que as coisas inanimadas existiram antes das vivas. É oportuno frisar que o organismo busca morrer ao seu modo pela força imanente a si, que é a própria pulsão de morte.

Nesse sentido, em termos especulativos, para Freud, a tensão inicial que surgiu na matéria inanimada se direcionou para neutralizar a si mesma e, consequentemente, possibilitar o surgimento da primeira pulsão, que é a pulsão voltada para retornar ao estado inanimado. Ocorre que, devido às influências externas, a substância viva passou a divergir de seu curso original e a adotar um número maior e mais complexo de mediações para atingir seu propósito, isto é, morrer ou retornar ao inanimado.

Como efeito dessa argumentação, as pulsões sexuais adquirem um estatuto específico e diferenciado, uma vez que essas pulsões são responsáveis pelo destino dos organismos elementares que sobrevivem à totalidade dos organismos mais elevados. É o caso das células germinais ou germinativas, que retêm a estrutura original da matéria viva e, após algum tempo, se separam do organismo como um todo, levando consigo os complementos de disposições pulsionais herdadas e adquiridas.

A consequência disso é que as pulsões sexuais, enquanto guardiãs desses organismos elementares, são também conservadoras em três sentidos específicos. No primeiro sentido, as pulsões sexuais são conservadoras no mesmo sentido das pulsões de morte, pois trazem o retorno de estados anteriores da substância viva. No segundo sentido, as pulsões sexuais são conservadoras na medida em que são resistentes às influências externas. Em um terceiro sentido, as pulsões sexuais são conservadoras ao preservarem a vida por um longo período. Logo, para Freud, as pulsões sexuais são as verdadeiras pulsões de vida, que estão em oposição direta às pulsões de morte.

A etapa seguinte do argumento de Freud nos conduz à parte VI de Além do princípio do prazer. Sua linha de pensamento reafirma o dualismo pulsional entre pulsões de morte e pulsões de vida. A questão que movimenta essa parte da argumentação de Freud diz respeito à relação entre o dualismo pulsional e a compulsão à repetição. Caso seja possível especular acerca da relação entre as pulsões de morte e a compulsão à repetição, devido ao caráter de retorno ao estado anterior, resta explicar em que medida as pulsões de vida estão ligadas a essa mesma compulsão, pois, do contrário, a estrutura do dualismo estaria comprometida.

Para desenvolver esse aspecto, Freud continua a recorrer ao modelo da biologia para testar e especular, primeiramente, pela validade da hipótese das pulsões de morte: "Devemos, portanto, voltar-nos para a biologia, a fim de testar a validade da crença" (FREUD, 1969, p. 64). A questão principal em torno desse momento da aproximação entre a hipótese de Freud e o modelo biológico diz respeito às origens da morte nos organismos vivos, visto que, se a morte é algo que foi originada nos organismos unicelulares, então esse modelo corrobora o argumento freudiano sobre as pulsões de morte estarem presentes desde o início. Se a morte é algo adquirido posteriormente pelos organismos vivos, isto é, nos organismos pluricelulares, o modelo biológico não confirma a hipótese de Freud.

Ocorre que Freud afirma que é possível identificar dois elementos a favor da hipótese das pulsões de morte. O primeiro está baseado na experimentação de que os protozoários podem morrer tais quais os organismos superiores, logo, há um retorno ao estado inanimado. O segundo elemento está assentado numa perspectiva dinâmica da compreensão dos fenômenos, em revelia à perspectiva morfológica. De acordo com a perspectiva dinâmica, é indiferente demostrar se existem pulsões de morte ou não nos organismos unicelulares, uma vez que essas forças podem estar presentes nos organismos unicelulares desde o início de suas atividades e estar ocultas pelas forças que preservam a vida. Isso significa que, se não é possível afirmar a existência das pulsões de morte, por outro lado também não é possível negar as mesmas. 
A exposição de Freud sobre as relações entre o dualismo pulsional e a compulsão à repetição é intercalada pela retomada da referência aos vínculos entre o princípio de constância e o princípio de prazer. Contudo, essa relação é pensada a partir do princípio de "Nirvana" em referência ao termo utilizado por Barbara Low. Nessa ocasião, é mencionado que a tendência dominante na vida mental e, talvez, na vida nervosa é o esforço para reduzir, manter constante ou remover a tensão interna dos estímulos. Freud entende que essa tendência tem como expressão o princípio de prazer e pode ser considerada uma forte razão para acreditar na existência das pulsões de morte.

Tal tendência encontra expressão no princípio de prazer, e o reconhecimento desse fato constitui uma de nossas mais fortes razões para acreditar na existência dos instintos de morte (FREUD, 1976, p. 76).

A partir desse ponto, o princípio de prazer surge como uma expressão do princípio de Nirvana. Além disso, a noção de "constância" é mencionada como integrante do princípio de prazer e, por consequência, expressão do próprio princípio de Nirvana. Isso nos leva até o conjunto de complexas relações que existem entre o princípio de constância, o princípio de prazer e a pulsão de morte.

Caso adotemos como referência o texto de Freud intitulado Projeto para uma psicologia científica, de 1895, é possível compreender com um pouco mais de precisão a natureza ambígua da relação entre o princípio de constância e o princípio de prazer. Nesse texto, o princípio de constância é considerado como sendo uma função secundária das exigências da vida decorrente de determinada modificação sofrida pelo princípio de inércia, o qual é a tendência dos neurônios de se esvaziarem da quantidade de excitação ou de fazer a evacuação completa da mesma.

Partindo dessa concepção da excitação neuronal como uma quantidade em estado de fluxo, pôde-se estabelecer um princípio básico da atividade neuronal em relação a $\mathrm{Q}$ que prometia ser extremamente elucidativo, visto que parecia abranger toda a função. Esse é o princípio da inércia neuronal: os neurônios tendem a se livrar de Q(FREUD, 1996, p. 356).

Dessa maneira, o princípio da constância, enquanto uma modificação do princípio de inércia, responde pela função secundária de manter a energia endógena, produzida pelo organismo, no nível mais baixo possível, tal qual se resguardar contra qualquer aumento da mesma, permitindo que ela permaneça constante, a partir de um determinado nível de tolerância, para a realização de uma ação específica. Essa ação específica depende da manutenção de alguma energia, portanto não ocorre o escoamento completo ou igual a 0 (zero), caracterizando um abandono da tendência original ou princípio de inércia.

Para efetuar essa ação (que merece ser qualificada específica), requer-se um esforço que seja independente da $Q \eta$ endógena e, em geral, maior, já que o indivíduo se acha sujeito a condições que podem ser descritas como as exigências da vida. Em consequência, o sistema nervoso é obrigado a abandonar sua tendência original à inércia (isto é, a reduzir o nível da $Q \eta$ a zero). Precisa tolerar a manutenção de um acúmulo de $Q \eta$ suficiente para satisfazer as exigências de uma ação específica. Mesmo assim, a maneira como realiza isso demonstra que a mesma tendência persiste, modificada pelo empenho de ao menos manter a $Q \eta$ no nível mais baixo possível e de se resguardar contra qualquer aumento da mesma - ou seja, mantê-la constante (FREUD, 1996, p. 357).

Para abordarmos com mais precisão o problema das relações entre princípio de constância, princípio do prazer e pulsões de morte, faremos uso da hipótese interpretativa intitulada "paradoxo do prazer" (MONZANI, 2014, p. 191). O pressuposto desse paradoxo decorre da maneira como são compreendidas e articuladas as definições a respeito do princípio do prazer. Caso a definição do princípio do prazer seja compreendida com ênfase na noção de "manutenção da constância" ou "conservação constante da qualidade”, o princípio de prazer estará subordinado ao princípio de constância. Entretanto, na hipótese 
de serem destacadas as ideias de "remover a tensão" ou "liberar inteiramente o aparelho mental de excitações", o princípio do prazer estabelece relações diretas com a pulsão de morte.

Isso tem consequências no paradoxo do princípio do prazer, cuja estrutura liga as duas compreensões mencionadas anteriormente. De um lado, o princípio do prazer parece ser o guardião da vida, pois tende a reconduzir o aparelho ao seu estado de funcionamento ideal. Por outro lado, o princípio de prazer fornece a impressão de expressar uma tendência ao escoamento total das tensões ou rumo a uma redução igual ao zero, correspondente à morte.

O núcleo ou raiz desse paradoxo repousa no fato de que como o princípio de prazer é composto pela noção de constância e, em certo sentido, deriva dela, então indiretamente a noção de inércia está presente nele também, visto que a ideia de constância é uma modificação ocorrida no princípio de inércia. Isso significa que o princípio de prazer, nos limites do texto de 1920, está relacionado à tarefa de eliminação dos excessos de tensão e de instauração de um estado de relativa constância. Ao mesmo tempo, o princípio de prazer também está relacionado ao zero da inércia e a sua evacuação energética completa. Por isso, o princípio de prazer possui essa dupla função, que é a evacuação relativa ou parcial para fins de constância ou evacuação absoluta tendente ao zero, cuja aproximação com a noção de pulsão de morte pode ser realizada de maneira imediata (MONZANI, 2014, p. 201).

Feito esse esclarecimento, o argumento retorna a atenção para o tema das relações entre as pulsões de vida e a compulsão à repetição. Sobre isso, Freud postula que esse problema pode ser abordado com base na ideia de que existem pulsões de vida que funcionam nos organismos mais simples, já que acontece a conjugação entre os mesmos, a qual é mantida, elaborada e não evitada. Essa afirmação reconduz à hipótese de que as pulsões de morte e as pulsões de vida estão relacionadas desde o início.

Do ponto de vista das origens da sexualidade, Freud sustenta que o modelo científico possui restrições para contribuir com sua especulação numa perspectiva dualista. Como consequência disso, ele recorre ao modelo poético-filosófico existente em $O$ banquete de Platão. A justificativa de Freud para fazer uso do modelo poético-filosófico reside no fato de esse modelo atribuir as origens das pulsões para uma necessidade de restaurar determinado estado anterior de coisas.

Freud está se referindo, precisamente, à fala de Aristófanes, segundo a qual, em algum momento, a natureza humana era dotada de três sexos (homem, mulher e a união dos dois). Tudo nesses sexos era duplo: quatro mãos, quatro pés, dois rostos, e assim por diante. Zeus decidiu cortar em duas cada uma dessas partes. Depois da divisão, cada uma das partes passa a desejar sua outra metade e, por consequência, se reúnem e se abraçam umas às outras com o propósito de se fundirem.

Em termos metapsicológicos, Freud, a partir do modelo poético-filosófico, especula e interroga sobre três aspectos específicos: 1) a substância viva pode ter sido dividida em pequenas partículas que realizam o esforço de voltarem a se reunirem umas às outras por meio das pulsões sexuais; 2 ) as pulsões conseguiram gradativamente superar as dificuldades impostas pelos estímulos perigosos e formaram uma camada cortical protetora; 3 ) os fragmentos estilhaçados da substância viva atingiram uma condição multicelular nas pulsões de união para as células germinais.

Dito isso, a linha argumentativa de Freud chega à sua parte final, isto é, à parte VII, na qual é mencionado novamente o problema da relação entre a compulsão à repetição e o domínio do princípio do prazer. Freud adverte que uma das funções mais antigas e importantes do aparelho psíquico é composta por um conjunto composto por três operações: sujeitar impulsos pulsionais, substituir o processo primário pelo processo secundário e converter a energia catéxica livremente móvel numa catexia principalmente tônica. 
Essa transformação energética ocorre em função do princípio do prazer. A operação da sujeição dos impulsos pulsionais é preparatória e introduz o domínio do princípio do prazer.

Freud desenvolve seu argumento apresentando a distinção entre função e tendência. O princípio do prazer é uma tendência que age a serviço de uma função. Conforme já apresentamos, o princípio do prazer tem três objetivos: libertar totalmente o aparelho psíquico de excitações, conservar a quantidade de excitação constante nele e/ou manter essa excitação o mais baixa possível.

A função, por sua vez, está relacionada com o esforço da substância viva em retornar à quiescência do mundo inorgânico. Assim, no dizer de Freud, o princípio de prazer, com sua dupla estrutura, serve às pulsões de morte. Por outro lado, especificamente nas situações de neurose de transferência, há uma compulsão à repetição que é totalmente independente ao princípio de prazer e pode chegar a se opor ao mesmo. Essa repetição é dotada de um alto grau pulsional que manifesta uma característica inerente à própria pulsão, a qual consiste na tentativa de retorno ao estado originário, isto é, à morte.

\section{A INVESTIGAÇÃO FILOSÓFICA DE DELEUZE ACERCA DO PRINCÍPIO DO PRAZER}

\section{PRIMEIRO MOMENTO DA APROPRIAÇÃO}

A interpretação filosófica realizada por Deleuze acerca de Além do princípio de prazer pode ser considerada de cunho transcendental e genealógico,7 uma vez que ela pergunta pelas razões que atribuem o "valor sistemático" de princípio para o prazer. Esse tipo de interrogação filosófica busca encontrar os princípios e condições que sustentam o próprio pensamento, contudo, também realiza uma investigação sobre as origens dos valores ligados a esses princípios e, em última instância, problematiza os modos de existência fundante desses valores.

$\mathrm{Na}$ esteira da pesquisa transcendental e genealógica, Deleuze apresenta em Sacher-Masoch sua compreensão a respeito da tarefa especulativa explicitamente mencionada. Deleuze entende a "especulação" de Freud como sendo uma pesquisa filosófica transcendental, a qual é caracterizada enquanto investigação ou reflexão sobre os princípios.

Qual é a ligação superior que faz do prazer um princípio, que lhe dá o status de princípio e lhe submete a vida psíquica? Pode-se dizer que o problema colocado por Freud é o contrário daquele que lhe é frequentemente imputado: trata-se não de exceções ao princípio do prazer, mas de fundação desse princípio. Trata-se da descoberta de um princípio transcendental: problema de "especulação", acrescenta Freud (DELEUZE, 2009, p. 111).

Um princípio é algo que rege um domínio, uma espécie de lei que atesta a regularidade de determinado âmbito de estudo. Mais especificamente, diz respeito ao prazer enquanto princípio que rege a vida psíquica no inconsciente. Entretanto, no argumento de Deleuze, ainda que não haja exceções ao princípio do prazer, existem singulares complicações ao prazer propriamente dito. Há um resíduo irredutível, exterior e heterogêneo em relação ao princípio do prazer.

Para investigar a possibilidade desse resíduo irredutível, surge a necessidade de identificar as razões que fizeram com que determinado domínio fosse submetido à regularidade de um princípio em particular. Para Deleuze, isso ocorre em função de um tipo de princípio de segundo grau, pois o princípio de primeiro grau governa o setor de algum domínio específico. Nesse caso, o domínio específico é a vida psíquica, o princípio de primeiro grau que a rege é o prazer e o princípio de segundo grau que relaciona a vida psíquica ao prazer recebe o nome de "transcendental". 
Deleuze afirma que a única coisa que não é regida pelo princípio do prazer e lhe permanece exterior é o "valor" de princípio que o prazer adquire na vida psíquica. Assim, não se trata de perguntar pela exceção ao princípio do prazer, mas pela sua fundação. Isso significa que o "Além” é interpretado por Deleuze não como "exceção" e sim como "fundação". Deleuze crítica e modifica o problema, equiparando o "especulativo" ao "transcendental", e constrói uma correspondência entre "Além" e "fundação". Por isso o enunciado passa a ser o seguinte: como, de um ponto de vista transcendental e genealógico, o prazer é fundado enquanto princípio?

De acordo com Deleuze, a resposta de Freud para essa pergunta consiste em postular que é a ligação o elemento que funda o prazer enquanto princípio. É a atividade da ligação que atribui valor sistemático para o processo de descarga de prazer. Deleuze afirma que, mesmo sem a ligação, existe prazer decorrente da descarga energética e consequente redução do nível de excitação do aparelho psíquico. Todavia, é a atividade de ligação que fornece um valor regular e sistêmico para o prazer. Ela funda o prazer enquanto princípio quando realiza a preparação para a primazia do mesmo dentro do aparelho mental, uma vez que a ligação opera a sujeição dos impulsos pulsionais que estão em choque e colisão na vida psíquica.

No argumento de Deleuze, a ligação é Eros enquanto fundamento que opera o duplo mecanismo da mesma. Ligação energética da excitação e ligação biológica das células. A segunda ligação funciona como meio ou conjunto de condições favoráveis para a primeira. Acerca disso, Deleuze afirma que a repetição é a dupla ligação que constitui Eros. Seja repetição com relação à excitação, seja repetição do momento da vida como união e conjunção até entre os organismos unicelulares.

Nesse ponto ocorre uma radicalização na pesquisa transcendental, uma vez que ela não pergunta apenas pela fundação ou fundamentação do prazer enquanto princípio, porém interroga também pelo sem-fundo que está relacionado ao fundamento ou fundo. Essa radicalização da pesquisa transcendental implica a necessidade investigativa e especulativa inerente à mesma, uma vez que não é possível interromper seu andamento sem comprometer tamanha necessidade.

A natureza da relação necessária entre fundo e sem-fundo corresponde à questão sobre a maneira como a repetição pode desempenhar um papel simultâneo de "ao mesmo tempo" e de "um antes" sem que um anule o outro. Entre o "ao mesmo tempo" e "um antes" existem diferenças de ritmo e desempenho, pois o "ao mesmo tempo" é caracterizado nos limites da dupla ligação, a qual ocorre simultaneamente para com a excitação e para com a vida.

O "ao mesmo tempo" é a repetição como Eros, o qual equivale ao fundo ou fundamento transcendental do prazer enquanto princípio empírico que rege a vida psíquica. O "um antes" é caracterizado como aquilo que é anterior à excitação romper a indiferença do inexcitável e anterior que à própria vida rompa ao sono do inanimado. Ele é o sem-fundo ou Tânatos que Eros carrega consigo. Eros e Tânatos, fundo e sem-fundo, são as duas faces da repetição, que podem ser "repetição laço", que liga, e "repetição borracha", que apaga.

Eros é a condição transcendental para a instauração do princípio empírico do prazer. Deleuze adverte que na experiência propriamente dita não é possível vivenciar nem Eros, nem Tânatos, já que nenhum dos dois é dado. A função do primeiro é ligar a energia do segundo e submeter suas combinações energéticas ao princípio do prazer. Eros age diretamente sobre o princípio do prazer, mas Tânatos permanece silencioso enquanto instinto de morte e instância que transcendente.

Dessa maneira, Deleuze afirma que a repetição é a síntese transcendental do tempo. A síntese transcendental do tempo é repetição do antes, do durante e do depois. Ela constitui no tempo o presente, o passado e o futuro. Entre o passado, o presente e o futuro há uma diferença qualitativa ou de natureza. Por 
isso, há uma repetição que liga e constitui o presente, uma repetição que apaga que constitui o passado e uma repetição que pode salvar ou não ser capaz de constituir o futuro: "Deve-se compreender que a repetição tal como Freud a concebe nesses textos geniais é em si mesma uma síntese do tempo, síntese transcendental do tempo" (DELEUZE, 2009, p. 113).

Interpretar a repetição dotada de duas faces, repetição laço e repetição borracha, enquanto síntese transcendental do tempo, significa também aproximar esse problema do tema do "eterno retorno". Para Deleuze, o eterno retorno em Nietzsche existe para resolver o seguinte problema: qual é o ser do devir? O eterno retorno é o retorno daquilo que difere e não o retorno do mesmo. $\mathrm{O}$ eterno retorno é constituído pelas múltiplas camadas da síntese: síntese do tempo e de suas dimensões, síntese do diverso e de sua reprodução, síntese do devir e do ser que se afirma do devir, síntese da dupla afirmação (DELEUZE, 1976, p. 24-34).

As sínteses são o próprio eterno retorno que tem a função de descobrir o ser do devir. O eterno retorno é sustentado pela vontade de poder. Ele é o ser do devir-ativo, uma vez que, de um ponto de vista físico, afirma o ser do devir. Mas do ponto de vista de uma ontologia seletiva, o ser do devir é corroborado como devir-ativo. O eterno retorno, para Deleuze, é o retorno daquilo que difere e não o retorno do mesmo, cuja razão suficiente é a vontade de potência. A vontade de potência é o elemento genealógico da força, pois é ao mesmo tempo diferencial e genético.

Tânatos, face do eterno retorno ou síntese transcendental do tempo, é o elemento seletivo que apaga, destrói, desfaz e desliga as relações energéticas e biológicas. Tânatos, relacionado a Eros, é a condição para o surgimento de forças ativas mediante a transformação das ligações das forças passivas. Ocorre que, do ponto de vista da experiência ou do vivido, nem Eros nem Tânatos são dados no mesmo, visto que são faces do princípio transcendental/genealógico da repetição. Eros funda o prazer enquanto princípio que rege a vida psíquica. Todavia, Eros só executa essa tarefa carregando Tânatos com ele. Essa relação entre Eros e Tânatos, fundo e sem-fundo, é marcada pelo fato de que o primeiro liga a energia do segundo e permite as combinações pulsionais no inconsciente.

Deleuze enfatiza que, mesmo não sendo dado na experiência, Eros se faz ouvir e age. Por outro lado, Tânatos é essencialmente mais silencioso e mais terrível. $\mathrm{O}$ efeito disso é que Tânatos passa a ser chamado por Deleuze de "instinto de morte”, o qual é a negação pura (MONTEBELLO, 2011, p. 17). Deleuze utiliza a palavra "instinto" em função do contexto semântico em vigor e do objetivo que ele pretende atingir, qual seja: absorver filosoficamente a discussão psicanalítica em torno das relações entre repetição e prazer. Essa absorção filosófica é de ordem genealógica/transcendental e visa modificar na experiência vivida a natureza da relação entre repetição e prazer.

Em Deleuze, a palavra "pulsão” designa as forças combinadas que compõem o inconsciente. Já o termo "instinto" nomeia, filosoficamente, o princípio transcendental que fundamenta e compõe as faces da repetição. As pulsões são representantes diretos de Eros e representantes indiretos de Tânatos - são os componentes das combinações determinadas que estão misturados no inconsciente: "Se Deleuze o chama instinto e não pulsão é para distingui-lo de toda pulsão destruidora, ruidosa, erotizada” (LAPOUJADE, 2015, p. 87).

Se a repetição, dentro da experiência vivida, é autônoma e independente em relação ao prazer, ele não é o critério necessário para seleção das forças e energias ou para a ligação e o desligamento. O prazer é efeito da seleção (conversão e transformação) e da ligação, ele é o coroamento vivido da redução da excitação e, em certo sentido, do desligamento enquanto externalização. 
Como consequência disso, Deleuze propõe que o meio para realizar a inversão entre o prazer e a repetição na experiência vivida é a perversão: "Não se deve concluir que Deleuze é um perverso, mas sim que ele instaura um procedimento ou um método perverso que consiste em uma espécie de duplo do original estudado, e que permite passar do outro lado do limite atribuído pelo original" (LAPOUJADE, 2015, p. 135). Na perversão ocorre um tipo específico de relação entre dessexualização e ressexualização. Essa relação é marcada pelos extremos da frieza e da força, cuja mediação é efetivada pela combinação entre intensidade e proporcionalidade. A força da ressexualização perversa será tão forte quanto a frieza da dessexualização.

O efeito do duplo processo dessexualização/ressexualização é a inversão da relação entre o prazer e a repetição. Nesse caso, a repetição se converte em ideia e o prazer em conduta. A repetição não fica apenas autônoma e independente em relação ao prazer, mas o prazer passa a seguir a repetição. Não se repete mais como decorrência do prazer ou para se obter o prazer. A dessexualização age sobre Eros para ressexualizar com mais força e conforto Tânatos ou o instinto de morte. Deleuze passa a impressão de despertar de maneira mais intensa o instinto de morte para promover uma poderosa repetição-borracha, abrindo os caminhos que conduzem ao problema da repetição "para si” mesma.

\section{SEGUNDO MOMENTO DA APROPRIAÇÃO}

O projeto de Diferença e repetição consiste numa pesquisa voltada para pensar a diferença "em si mesma" e na relação do diferente com "o diferente", o qual está necessariamente ligado ao aspecto da repetição complexa "para si mesma". Não só isso, esse projeto também se desenvolve na esteira da "inversão do platonismo", que está relacionado à teoria da Ideia (matéria intensiva e movimento da matéria) e à síntese disjuntiva, enquanto sistema aberto de relações heterogêneas entre termos díspares que se determinam mutuamente.

Sendo assim, o capítulo 2 de Diferença e repetição, cujo título é "A repetição para si mesma", pode ser considerado a principal fonte de acesso à interpretação que Deleuze realiza a respeito do texto de Além do princípio do prazer, de Freud. O objetivo geral desse capítulo de Diferença e repetição consiste em investigar a repetição "para si mesma", isto é, a maneira como a repetição pode ser pensada por meio das sínteses passivas do tempo.

Existem três sínteses passivas do tempo. Elas são o processo de constituição, fundação e fundamentação do tempo, bem como de sua metamorfose no sentido de estabelecer a repetição como pensamento e produção do absolutamente diferente, o qual corresponde à repetição "para si mesma", que é indissociável da diferença "em si mesma”. Assim, Deleuze retoma mais uma vez o problema central de Além do princípio do prazer: em que medida o prazer pode ser considerado um princípio? O pressuposto da pesquisa de Deleuze consiste em interpretar o "Além" como sendo o conjunto de condições sobre as quais o prazer se torna efetivamente um princípio.

Respeitando as exigências de um empirismo superior (DELEUZE, 2006, p. 94), em que a pergunta pelas condições significa interrogar pelas condições da experiência real, na qual o condicionante não pode ser maior do que o condicionado, a fim de formar a identidade entre o objeto e conceito, a questão de Deleuze pode receber a seguinte formulação: quais são as condições da experiência real que permitem que o prazer adquira o valor sistemático e seja considerado um princípio?

A resposta de Deleuze ocorre nos termos das regras do jogo da diferença e da repetição. Não apenas isso, de maneira mais específica, Deleuze utiliza as três sínteses do tempo para construir sua resposta. Cada uma das três sínteses equivale a uma condição que sustenta o valor sistemático do prazer enquanto 
princípio. Então, o "Além" é composto por três condições. Numa perspectiva transcendental e genealógica, existem três condições que estão interligadas, capazes de sustentar o valor princípio do prazer.

Por isso, durante a investigação de Deleuze acerca desse problema, também ocorre uma apropriação crítica de inúmeros conceitos psicanalíticos, os quais vão desde a noção de excitação, passando por uma teoria da constituição do aparelho psíquico até a recusa do modelo do dualismo conflituoso para pensar o inconsciente e a repetição material para pensar a própria repetição e a morte. Sem deixar de apresentar a correspondência entre cada uma das sínteses e cada uma das instâncias que constituem o aparelho psíquico. Cada uma das sínteses equivale em ordem e, respectivamente, ao Id, ao Ego e ao Superego.

Com exceção feita à primeira síntese, cada uma das outras surge da necessidade proveniente do limite atingido pela síntese anterior. A primeira síntese pode ser considerada uma exceção nesse movimento entre necessidade-limite-necessidade, devido ao fato de ela não decorrer da necessidade causada pelo limite de uma síntese anterior. O elemento peculiar é que na segunda síntese não há apenas um limite que clama por necessidade, mas uma verdadeira crise do tempo e do fundamento do mesmo.

Nesse sentido, a primeira síntese passiva é o hábito ou presente vivo, a qual decorre da contração, modificação, fusão ou extração da diferença à repetição com o propósito de constituir uma qualidade nova. Ela funciona como fundação do tempo e é o sistema do sujeito larvar enquanto "eu dissolvido" ou "eu passivo". A síntese passiva não é feita pelo espírito, mas é feita no espírito, precedendo toda memória e toda reflexão. São mil hábitos, contrações, contemplações, pretensões, presunções, satisfações, fadigas e presentes variáveis.

Nessa síntese a repetição é constituída por três instâncias: "em si", "para si" e "para nós". O "em si" é a instância que deixa a repetição impensável ou que a desfaz na medida em que ela se faz. O "para si" é a instância que corresponde à síntese passiva. $\mathrm{O}$ "para nós" são as sínteses ativas fundadas como representações refletidas sobre as sínteses passivas. A síntese passiva é a duração.

Seu limite é a característica da intratemporalidade, a qual prega que o hábito, no mesmo movimento, constitui o presente como tempo na medida em que o presente tem a pretensão de passar. A intratemporalidade conduz ao paradoxo do presente, cuja resolução depende de outra síntese do tempo mais profunda, a qual é a segunda síntese ou o passado puro. Essa segunda síntese não funda o tempo, mas fundamenta o mesmo e exerce pressão sobre o presente vivo da primeira síntese para que ele ambicione passar. Nesse sentido, Deleuze distingue duas operações filosóficas: a fundação e o fundamento. A fundação é composta por um solo, pelo estabelecimento nesse solo, seguido de sua ocupação, e culmina em sua posse. É um movimento horizontal (DELEUZE, 2006, p. 123).

O fundamento vem do céu, pois vai do ápice às fundações, avaliando o solo e o possuidor de acordo com o título de propriedade. É um movimento vertical. Por isso, a memória é o fundamento do tempo enquanto aquilo que faz o presente passar. A memória é a segunda síntese do tempo ou síntese passiva mais profunda do que o hábito. O fundamento da memória é o passado puro (DELEUZE, 2006, p. 124).

O passado puro funciona a partir de quatro paradoxos: contemporaneidade, coexistência, preexistência e a metáfora do cone. A contemporaneidade fornece a razão do presente que passa, uma vez que o passado é contemporâneo de si como todo presente que passa em proveito de um novo presente. O paradoxo da coexistência propõe que todo passado coexiste com o novo presente em relação ao qual ele é passado. A preexistência dispõe que o elemento puro do passado em geral preexiste ao presente que passa. Logo, existe um elemento substancial do que exerce o papel de fundamento, que por sua vez não é representado. Para os fins da representação, aquele que logra êxito é o presente antigo ou o presente atual, e não o passado puro. A metáfora do cone, como quarto paradoxo, prega que o presente é o grau mais contraído do 
passado que com ele coexiste. Isso ocorre desde que o passado coexista consigo numa grande variedade de outros tantos graus contraídos e descontraídos.

O limite da segunda síntese passiva enquanto fundamento do tempo está relacionado à dificuldade de acesso ao passado puro. A reminiscência ou memória involuntária é caminho proposto por Deleuze para tanto. Ocorre que a memória involuntária está necessariamente ligada a Eros, pois ela é uma memória erótica. Como consequência, o limite extremo da segunda síntese do tempo consiste em saber a natureza da força capaz de fazer com que a exploração pelo passado necessite de Eros (DELEUZE, 2006, p. 131).

A terceira síntese do tempo é o eterno retorno ou o futuro enquanto tal. Mais precisamente é chamado de "crença do futuro" ou "crença no futuro". É a repetição do futuro como eterno retorno, a qual é uma condição da ação antes mesmo de ser um conceito da reflexão. $O$ eterno retorno é a repetição por excesso que funciona como a forma do tempo pura e vazia capaz de desfazer o círculo temporal simples em favor do círculo mais complexo, cujo propósito é atravessar o fundamento na direção de um sem fundo (DELEUZE, 2006, p. 141).

Essa travessia, dotada de pura metamorfose universal, gira em torno de si mesma e faz retornar o por vir. Portanto, o eterno retorno é a efetividade da uma filosofia da repetição que passa pelos estágios concernentes às duas sínteses anteriores, ou seja, afirma o caráter incondicionado do produto em relação à sua condição. $\mathrm{O}$ eterno retorno permite que a repetição seja o pensamento e a produção do absolutamente diferente que corresponde à "repetição para si mesma".

Posto isso, Deleuze começa a construir sua resposta para transformação do prazer em princípio adotando como critério, "lupa" e medida as três sínteses e os laços de necessidade entre cada uma. Sua resposta propõe que a ligação ou investimento que age sobre a excitação enquanto diferença livre permite que seja atribuído ao prazer o valor sistêmico de princípio. Essa ação de ligação é operada pela primeira síntese passiva do tempo ou presente vivo, que também é chamada de "hábito".

É evidente que o prazer dá prazer, mas de modo algum esta é uma razão para que ele adquira um valor sistemático, segundo o qual é procurado "por princípio". É o que significa, inicialmente, para "além" do princípio de prazer: de modo algum se trata das exceções a este princípio, mas, ao contrário, da determinação das condições sob as quais o prazer efetivamente princípio. A resposta freudiana é de que a excitação, como diferença livre, deve, por assim dizer, ser "investida", "ligada", amarrada, de tal maneira que sua resolução seja sistematicamente possível. Mas o hábito, como síntese passiva de ligação, precede, ao contrário, o princípio de prazer e o torna possível (DELEUZE, 2006, p. 145).

Essa ligação ou investimento corresponde à representação de uma segunda potência da repetição, visto que a primeira potência corresponde à contração ou diferença que é extraída de uma repetição elementar. Como decorrência da ligação ou síntese passiva surge um duplo movimento da própria ligação: ultrapassagem e aprofundamento (DELEUZE, 2006, p. 148).

A ultrapassagem é operada por uma síntese ativa que surge a partir da primeira síntese passiva. Nessa síntese ativa ocorre a ligação junto a determinado objeto que seja apresentado como real. Essa ligação corresponde à série dos objetos reais, que por sua vez corresponde às pulsões de conservação. Essa série dos reais se subdivide necessariamente entre duas outras séries, cada qual corresponde a um tipo de presente: antigo presente e presente atual.

No aprofundamento ocorre um movimento de ligação junto aos objetos virtuais em que a excitação ligada é utilizada para atingir alguma outra coisa. Isso permite construir a série dos objetos virtuais, que 
corresponde às pulsões sexuais. As séries dos objetos virtuais e dos objetos atuais são complementares e dessemelhantes entre si, marcadas primordialmente pelas diferenças de natureza.

Do ponto de vista de sua origem e de sua natureza, os objetos virtuais decorrem de duas operações sucessivas realizadas junto à série dos reais: destacamento e incorporação. $O$ destacamento é uma suspensão para extrair da série dos reais uma parte qualitativa, a qual adquire uma nova natureza ao funcionar como objeto virtual. A incorporação, que equivale ao destacamento, equivale a fixar e testemunhar no objeto real a outra metade que falta ao próprio objeto virtual.

Com base nisso, de acordo com Deleuze, os objetos virtuais são objetos parciais (DELEUZE, 2006, p. 150) devido a pelo menos três razões: falta uma parte que permaneceu no real, ele se divide e se desdobre em duas partes virtuais em que uma falta à outra, bem como o virtual não está submetido ao caráter global que afeta os objetos reais. $\mathrm{O}$ objeto virtual é um trapo, um fragmento e um despojo que está sempre no passado puro, ou seja, no passado que é contemporâneo ao presente.

Além disso, ao fundo do objeto virtual grita sua característica mais importante: o deslocamento. O deslocamento não significa que o objeto virtual apenas se mova entre a série dos reais e dos virtuais. $\mathrm{O}$ deslocamento enfatiza a divisão, transformação e movimentação do objeto virtual em relação a si mesmo, assegurando que algo sempre falta em uma de suas metades, bem como que algo falte também à sua identidade, à sua representação, ao seu lugar, sem nunca haver um termo último.

Sob todos os objetos virtuais está o "falo" ou "objeto = x", que pode ser considerado a causa da memória involuntária ser sempre erótica. É o objeto = x que atrai o aprofundamento da ligação da síntese passiva junto aos objetos virtuais. O limite da segunda síntese, a necessidade de uma exploração erótica do passado puro, encontra sua resposta ou superação na noção de objeto virtual, visto que ele é o órgão simbólico que relaciona Eros à memória involuntária. Eros, por fim, arranca fragmentos, pedaços e trapos do objeto virtual, alimentando nossas reminiscências e possibilitando que o passado puro possa ser visitado e sustentado como fundamento do próprio tempo.

Ocorre que a série dos reais, a qual corresponde às pulsões de conservação e deriva da ultrapassagem da primeira síntese passiva na direção da síntese ativa ligada a um objeto colocado como real, se subdivide em outras duas séries que equivalem, respectivamente, ao antigo presente e ao presente atual. Essas duas séries são organizadas em função do objeto virtual enquanto objeto $=\mathrm{x}$.

Nenhuma das séries reais é considerada como original ou derivada em relação à outra. Elas surgem e funcionam em função do movimento ou circulação do objeto virtual que modifica a si e aos termos das séries na medida em que percorre ambas, colocando-se sempre entre as duas. $\mathrm{O}$ efeito disso é a repetição constituída como disfarce dos termos e das relações entre termos que afetam as séries. A repetição como disfarce deriva da imanência referente ao deslocamento do objeto virtual. Portanto, a repetição é imanente ao objeto virtual e seu disfarce concerne ao mesmo.

Sendo assim, o objeto virtual é uma máscara que está sempre por trás de outra máscara e que sucede outra máscara e assim sucessivamente. A máscara é disfarce e deslocamento perpétuos. Disfarce, porque afeta os termos e as relações entre eles nas duas séries dos reais. Deslocamento, visto que afeta o objeto virtual simbólico em sua série, bem como nas séries reais em que ele circula.

Como consequência disso, Deleuze afirma que o objeto virtual permite que a repetição seja pensada fora dos quadros da repetição material, a qual a teoria da compulsão à repetição está submetida. O modelo da repetição material é caracterizado por ser de ordem realista, materialista e solipsista. Realista, pois tudo ocorre entre os presentes. Materialista, já que lida com os componentes do automatismo e da 
repetição bruta. Solipsista, visto que os termos da repetição são considerados como representações. Para Deleuze, o modelo material subordina a repetição às exigências da representação, o que impede que a própria repetição seja pensada em "para si” mesma.

A teoria tradicional da compulsão à repetição, em psicanálise, permanece essencialmente realista, materialista e subjetiva ou individualista. Realista, porque tudo se "passa" entre presentes. Materialista, porque o modelo de uma repetição bruta, automática, permanece subjacente. Individualista, subjetiva, solipsista ou monádica, porque o antigo presente, isto é, os termos atuais da repetição travestida são considerados somente como representações do sujeito, representações inconscientes e conscientes, latentes e manifestas, recalcantes e recalcadas (DELEUZE, 2006, p. 154).

Esclarecido isso, Deleuze caracteriza a segunda síntese, marcada pelo disfarce e deslocamento do objeto virtual, como aquela que fundamenta o princípio do prazer. Se a primeira síntese, o hábito, foi capaz de fundar o princípio do prazer, a segunda síntese, do objeto virtual, fundamenta semelhante princípio. Entretanto, a segunda síntese é dotada de um limite, pois ainda que o objeto virtual explique o caráter erótico da memória involuntária, ele também contribui para uma forte ambiguidade.

Essa ambiguidade entre Eros e a memória involuntária é formada pela confusão entre a série dos virtuais e as séries dos reais. Semelhante confusão decorre do movimento de ordem circular, divergente e diferencial, que é inerente ao objeto virtual. Esse movimento faz com que essas séries efetuem também uma movimentação circular e divergente umas em relação às outras desde a ultrapassagem e o aprofundamento que está presente na primeira síntese.

A consequência disso é a produção de sucessivas ilusões que são o núcleo da ambiguidade entendida como limite da segunda síntese. Essas ilusões concernem à identidade da origem, à semelhança no derivado e à ilusão de um originário. É a forma do movimento do próprio objeto virtual que conduz a essa ambiguidade, pois no fundo é a forma do movimento do tempo que está em questão na segunda síntese, o qual encontra seu limite como círculo físico ou natural bem centrado.

Deleuze argumenta que essa inevitável confusão entre a série virtual e as séries reais culmina numa quebra do círculo pelo qual Eros arrastava consigo todo conteúdo memorial, ou seja, sua relação com a memória involuntária. Esse rompimento do círculo em que Eros realizava seu movimento equivale ao processo de dessexualização, isto é, a formação de uma energia neutra capaz de se deslocar. Isso significa que o círculo físico ou natural bem centrado mudou sua forma, pois não se trata mais sequer de um círculo, porém de uma linha reta. A mudança da imagem expressa necessariamente uma mudança no caráter do tempo (DELEUZE, 2006, p. 164). A violência da movimentação do objeto virtual retirou o tempo de seus eixos, conduzindo-o para a terceira série, que é a do tempo vazio.

De acordo com Deleuze, a dessexualização de Eros corresponde inteiramente à constituição de Tânatos. Essa constituição está ligada à energia livre que pode ser deslocada. Entre Eros e Tânatos existe uma diferença sintética que é caracterizada pela terceira síntese enquanto tempo vazio de conteúdo, dotado de uma energia livre que pode ser utilizada como violência para a gênese do ato de pensar dentro do próprio pensamento.

Tânatos também funciona na terceira síntese como uma crítica e uma alternativa ao modelo de morte adotado por Freud, ou seja, aquilo que Deleuze denomina "modelo objetivo": “Todavia, é ao primeiro aspecto que remete toda a concepção freudiana: mas é assim que ela falseia o instinto de morte e a experiência ou o protótipo correspondentes" (DELEUZE, 2006, p. 167). Esse modelo objetivo é constituído pela redução da morte à determinação objetiva da matéria, em que a repetição adota como princípio último um modelo material indiferenciado. 
Claro que Deleuze está sempre invocando Freud, mas sobre esse último ponto a relação é duvidosa, como O Anti-Édipo confirmará posteriormente; pois, enquanto em Freud, Tânatos tende a nos reconduzir rumo a um indiferenciado que a matéria encarna idealmente, em Deleuze permite, ao contrário, a afirmação da maior diferença e se confunde não mais com a matéria inerte, mas com uma forma pura adequada à ascensão do informal ou do sem-fundo em nós (LAPOUJADE, 2014, p. 88).

Ainda nesse tipo de morte existe o desaparecimento pessoal da pessoa que pode ser representado pelo retorno à matéria inanimada. Em contraposição a isso, Deleuze propõe a morte a partir do estado de diferenças livres que não estão submetidas a uma forma pessoal. É um "morrer-se" mais profundo do que "eu morro", que está presente no vivente como algo subjetivo resultante de uma diferenciação, a qual termina por corresponder à forma vazia do tempo.

Dir-se-ia que o tempo abandonou todo conteúdo mnemorial possível e, assim, quebrou o círculo onde Eros o arrastava. Ele se desenrolou, se endireitou, tomou a última figura do labirinto, o labirinto em linha reta, que é, como diz Borges, "invisível, incessante". O tempo vazio fora dos eixos, com sua ordem formal e estática rigorosa, seu conjunto esmagador, sua série irreversível, é exatamente o instinto de morte. O instinto de morte não entra num ciclo com Eros, não é de modo algum complementar ou antagonista deste $e$ de maneira alguma simétrico a este, mas dá testemunho de uma síntese totalmente distinta (DELEUZE, 2006, p. 164).

Por isso, Tânatos, na terceira síntese, é o sem-fundo que está além do fundamento e da fundação. Nesse ponto, Deleuze retoma o argumento do texto de 1967, Sacher-Masoch. A relação entre Tânatos e o prazer enquanto princípio é concebida nos termos da frieza da dessexualização e da força da ressexualização, tal qual ocorria no perverso. Nessa ressexualização, ocorrida a partir de Tânatos, a imagem do tempo sofre uma nova mudança, pois ela deixa de ser reta e volta a ser uma curva que age mais uma vez como um círculo. Contudo é um círculo eternamente descentrado ou singularmente tortuoso que equivale ao incondicionado do tempo, ${ }^{10}$ cuja face é o eterno retorno (DELEUZE, 2006, p. 169). O eterno retorno é a potência de afirmar tudo do múltiplo, do acaso e do diferente. Essa tarefa de pura afirmação está em relação direta com a morte, a qual permite que tamanha força ontológica-cosmológica-física-ética afirme a morte do uno em favor do futuro como desdobramento e explicação do múltiplo.

Semelhante força incondicionada cristaliza a jornada dos três aspectos do "Além", os quais funcionam como três condições, três sínteses e três momentos da repetição: laço, mancha e borracha. A repetição, enfim, exerce seu estatuto de repetição borracha ou aquela que muda a forma do tempo e funciona como derradeira condição para que o prazer seja considerado um princípio.

\section{CONSIDERAÇÕES FINAIS}

É apropriado retomarmos nosso problema: em que consiste a interpretação de Gilles Deleuze a respeito do texto Além do princípio do prazer, de Sigmund Freud? Supomos que a interpretação filosófica de Deleuze se aproprie do aspecto "especulativo" de fundo metapsicológico-econômico presente no texto de Freud. Esse aspecto especulativo está exposto e desenvolvido com maior riqueza de detalhes na parte IV de Além do princípio do prazer. Sua apropriação é de ordem crítica, transcendental e genealógica, tanto num âmbito esquemático quanto numa perspectiva conceitual.

Para desenvolver essa hipótese, nosso itinerário apresentou o conceito de princípio do prazer e sua eventual relação com a compulsão à repetição em Além do princípio do prazer de Freud. Em seguida, nosso 
percurso descreveu a compreensão de Deleuze acerca do princípio do prazer tal qual está exposta no livro Sacher-Masoch - O frio e o cruel.

Constatamos que nesse texto Deleuze equipara o "especulativo" ao "transcendental" e o "Além" é equiparado à "condição" que atribui o valor de princípio para o prazer. Essa condição é a ligação, que é tanto energética quanto biológica. A ligação é dotada de duas faces: Eros e Tânatos. Eros é o fundo ou a ligação-laço, já Tânatos é o sem-fundo ou a ligação-borracha. Essa dupla face da ligação equivale à repetição, que é a própria síntese transcendental do tempo.

Ocorre que, de um ponto de vista da experiência, a repetição está submetida ao prazer. Para que seja efetivada uma inversão que possibilite a autonomia da repetição, bem como ela seja qualificada como "condição" e não como "conduta", é necessário que haja uma intensa dessexualização ou desligamento energético, que carece de ser sucedido por uma forte ressexualização ou religação. Para Deleuze, isso só acontece com a devida eficácia na perversão.

Na segunda parte de nosso percurso, caracterizamos o argumento de Deleuze a respeito das condições que sustentam o prazer enquanto princípio no capítulo 2 de Diferença e repetição, "A repetição para si mesma”. Nesse capítulo, Deleuze mantém a estrutura esquemática de equiparar o "Além" às "condições" que atribuem o valor de princípio para o prazer. Existem três condições, as quais correspondem a três sínteses, três momentos da repetição e três imagens do tempo.

A primeira síntese é o hábito, a segunda o objeto virtual e a terceira o eterno retorno. O hábito funda o prazer como princípio, o objeto virtual fundamenta e o eterno retorno transforma, garantindo a abertura para o múltiplo. Cabe ressaltar que o eterno retorno é a face excessiva e intensa do instinto de morte ou Tânatos, que aparece quando a ambiguidade inerente ao objeto virtual atinge seu limite, o qual resulta do duplo movimento da síntese passiva do hábito. Esse duplo movimento é composto pela ultrapassagem e pelo aprofundamento. Entre o hábito e o objeto virtual, o tempo é dotado de uma circularidade natural e centralizada. No limite entre o objeto virtual e Tânatos, o tempo passa a ser linear e reto, que atinge também seu segundo limite com o eterno retorno, promovendo o tempo para uma nova circularidade descentrada e excessiva.

Embora haja certa continuidade esquemática, existe uma distinção fundamental entre 1967 e 1968. No livro de 1967, há duas repetições: laço e borracha. No texto de 1968, estão presentes três repetições: laço, mancha e borracha. Essa segunda repetição que equivale à segunda síntese do tempo está relacionada à importância do objeto virtual e à breve aliança com Lacan, visto que, nessa ocasião, Deleuze também buscava contribuir com o projeto de uma filosofia do estruturalismo que fosse capaz de ultrapassar o próprio estruturalismo. No entanto, essa aliança temporária encontra seu limite na ambiguidade oriunda da movimentação que pertence ao objeto virtual e, por consequência, faz com que Deleuze reafirme a força do programa nietzschiano em seu pensamento por meio da relação entre Tânatos e o eterno retorno.

Dessa maneira, a interpretação de Deleuze sobre Além do princípio do prazer, de Freud, postula que, em última instância, o prazer adquire seu valor de princípio a partir do sem-fundo incondicionado que descentra o tempo para afirmar, seletivamente, o devir-ativo do múltiplo, ou seja, do eterno retorno enquanto face de Tânatos. Esse incondicionado permite problematizar o modelo objetivo e pessoal da morte adotado por Freud, vindo a falar em favor de uma morte impessoal ligada à experiência subjetiva.

A grandeza desse incondicionado consiste em emitir o grito que tenta transformar as operações que estão envolvidas no princípio do prazer em forças ativas. Assim, em termos deleuzeanos, ligar, desligar e religar são processos produzidos pelas condições transcendentais e genealógicas que permitem a ascensão do prazer à categoria de regularidade sistêmica do aparelho psíquico. Eles atuam com violência na 
ativação da gênese do ato de pensar dentro do próprio pensamento. $\mathrm{O}$ incondicionado grita para se fazer escutar através dos ruídos do tempo.

\section{REFERÊNCIAS BIBLIOGRÁFICAS}

DAVID-MÉNARD, M. 2014. Deleuze e a psicanálise. Tradução de Marcelo Jacques de Moraes. Rio de Janeiro: Civilização Brasileira.

2015. Como ler Além do princípio do prazer? Tradução de Bernardo Maranhão. Reverso. Belo Horizonte, ano 37, número 69, p. 99-112, junho.

DELEUZE, G. 1999. Bergsonismo. Tradução de Luiz B. L. Orlandi. São Paulo: Ed. 34. . 1992. Conversações. Tradução de Peter Pál Pelbart. São Paulo: Ed. 34.

Rio de Janeiro: Graal. . 2006. Diferença e repetição. Tradução de Luiz Orlandi e Roberto Machado. . 2009. Sacher-Masoch - O frio e o cruel. Tradução de Jorge Bastos e revisão técnica de Roberto Machado. Rio de Janeiro: Zahar.

. 1976. Nietzsche e a filosofia. Tradução de Ruth Joffily Dias e Edmundo Fernandes Dias. Rio de Janeiro: Editora Rio.

DOSSE, F. 2010. Gilles Deleuze e Félix Guattari: biografia cruzada. Tradução de Fátima Murad. Porto Alegre: Artmed.

FREUD, S. 1976. Além do princípio do prazer. Tradução de Jayme Salomão e Cristiano Monteiro Oiticica. Rio de Janeiro: Imago Editora.

de Janeiro: Imago Editora. 1996. Projeto para uma psicologia científica. Tradução de Jayme Salomão. Rio

LACAN, J. 1998. Escritos. Tradução de Vera Ribeiro. Rio de Janeiro: Jorge Zahar.

LAPOUJADE, D. 2015. Deleuze, os movimentos aberrantes. Tradução de Laymert Garcia dos Santos. São Paulo: N-1 edições.

MONTEBELLO, P. 2011. L'instinct de mort chez Deleuze La controverse avec La psychanalyse. Curitiba/São Carlos, Revista dois pontos, vol. 8, número 2, p. 15-26, outubro.

MONZANI, L. R. 2014. FREUD - O movimento de um pensamento. Campinas: Unicamp.

PELBART, P. 1998. O tempo não-reconciliado. São Paulo: Editora Perspectiva. 


\section{NOTAS}

1. Professor assistente da UFMA e doutorando em Filosofia pela UFSCar. O autor agradece a instituição maranhense pelo apoio concedido à sua pesquisa doutoral.

2. DOSSE, 2010, p. 157-171.

3. Acerca das distinções e aproximações entre Deleuze e Freud do ponto de vista da repetição e da clínica, cf.: DAVID-MÉNARD, 2014, p. 142-155.

4. Não desconsideramos a importância de Além do princípio do prazer para o tema da "reviravolta" no pensamento de Freud, nem de seu traço "labiríntico", o qual remete para a dificuldade em detalhar a linha argumentativa do mesmo, bem como não ignoramos as relações entre prazer e desprazer no capítulo VII de $A$ interpretação dos sonhos de 1900 e suas aproximações com o texto de 1920. Porém, nos limites da presente exposição, não temos condições de nos aprofundar com maiores detalhes nesses aspectos.

5. O uso do modelo biológico pode ser compreendido como resultante da passagem da noção de "ligação" enquanto algo independente para ideia de um princípio de funcionamento mais original em relação ao princípio do prazer. Não só isso, o modelo biológico também é capaz de contribuir para esclarecer os paradoxos da repetição e, eventualmente, fornecer condições para uma especulação na perspectiva dualista, aproximando o desenvolvimento dos seres vivos e a sexualidade humana. Cf.: DAVID-MENARD, 2015, p. 101-108.

6. O problema central do livro Sacher-Masoch - O frio e o cruel, de 1967, consiste no seguinte: tomando como base a unidade sadomasoquista, em que medida é possível resgatar os elementos diferenciais e as originalidades artísticas inerentes aos valores literários de Sade e Masoch? Cf.: DELEUZE, 2009, p. 12-14.

7. A pergunta pelo valor de um princípio empírico está esquematicamente baseada naquilo que Deleuze atribui a Nietzsche em Nietzsche e a filosofia de 1962. Nesse texto Deleuze afirma que o pensamento de Nietzsche é uma pesquisa genealógica/transcendental. O pressuposto para esse empreendimento é a noção do trágico. O trágico é a proposta de um princípio transcendental para o pensamento que afirme a vida, a alegria, o devir e o múltiplo, ao mesmo tempo que busca liberar o pensamento de todo niilismo e suas formas (ressentimento, vingança e má consciência). Além disso, a essência do trágico é o pluralismo das forças que estão presentes nas coisas e determinam o complexo de sentidos das mesmas, pois o trágico está na diversidade da afirmação enquanto tal. Dessa maneira, o problema da filosofia crítica ou genealogia é a avaliação dos valores ou o "valor" dos valores. Cf.: DELEUZE, 1976, p. 4-15.

8. Parece ser um ponto pacífico o fato de que o eterno retorno em Nietzsche é um conceito inacabado, do qual, mesmo assim, é possível extrair alguns elementos importantes para a pesquisa filosófica: tempo cíclico, infinito, metamorfoseante, sem ter finalidade alguma e resultante da combinação entre inúmeras forças. O trabalho de Deleuze não deixa de ser uma tentativa de absorção e desenvolvimento do programa nietzschiano. É oportuno frisar que pistas, traços e caracterizações sobre o eterno retorno podem ser encontrados, por exemplo, no aforismo 341 de $A$ Gaia Ciência, aforismo 56 de Além de bem e mal e na carta de 5 de janeiro de 1889 que Nietzsche enviou para Burckhardt.

9. Para maiores detalhes de como a noção de falo é desenvolvida e trabalhada por Lacan, cf.: LACAN, 1998, p. 692702.

10. Sobre a contraposição entre as imagens linear e paradoxal do tempo na filosofia de Deleuze, cf.: PELBART, 1998. 